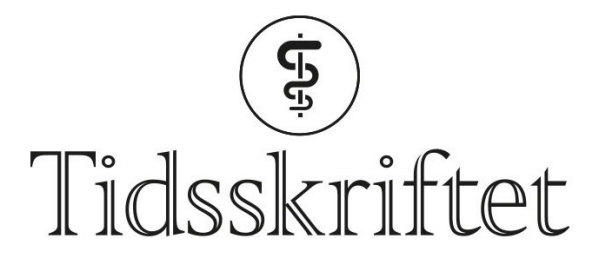

DEN NORSKE LEGEFORENING

\title{
P. Gjersvik \& I. Roscher svarer
}

KOMMENTAR

\section{PETTER GJERSVIK}

E-post: petter.gjersvik@medisin.uio.no

Petter Gjersvik er professor ved Institutt for klinisk medisin ved Universitetet i Oslo. Ingen oppgitte interessekonflikter.

\section{INGRID ROSCHER}

Ingrid Roscher er overlege ved seksjon for hudsykdommer ved Oslo universitetssykehus. Ingen oppgitte interessekonflikter.

Valg av ord er viktig. Det kan være vanskelig å forklare medisinske forhold til lekfolk. Norske ord er vanligvis å foretrekke fremfor latinske og greske. Så langt er Berger og vi enige.

Vi er derimot uenige med Berger om at «føflekkreft på en glimrende måte beskriver forskjellen mellom en normal føflekk og en melanom». Tvert imot mener vi at ordet føflekkreft tilslører det faktum at de fleste melanomer oppstår fra hud utenfor føflekker og avviker i utseende fra føflekker. Ordet fremmer en forestilling om at føflekker er forstadier til melanom. Dette skaper helseangst og unødig legesøkning.

Utviklingen i ordbruk fra sukkersyke til diabetes og blærehalskjertel til prostata har vært gradvis. I en overgangsperiode kan det foretrukne ordet brukes med det gamle i parentes, i dette tilfellet slik: melanom (føflekkreft).

Publisert: 28. mai 2018. Tidsskr Nor Legeforen. DOI:10.4045/tidsskr.18.0376

(C) Tidsskrift for Den norske legeforening 2020. Lastet ned fra tidsskriftet.no 